УДК 336.71

Мостовенко Н.А., к.е.н, доцент

Mostovenko N., Candidate of Economic Sciences, Associate Professor, https://orcid.org/0000-0002-2050-1529

Коробчук T.I., к.е.н., доцент

Korobchuk T. Candidate of Economic Sciences, Associate Professor, https://orcid.org/0000-0002-0356-4157

Чиж Н.М., к.е.н, доцент

Chyzh N., Candidate of Economic Sciences, Associate Professor, https://orcid.org/0000-0002-8183-1951

\title{
ОСНОВНІ ТЕНДЕНЦІЇ РОЗВИТКУ СУЧАСНОГО РИНКУ КРЕДИТНИХ ПОСЛУГ В УКРАЇНІ
}

\author{
Луцький національний технічний університет
}

\begin{abstract}
Для розширення господарської діяльності та забезпечення безперервності господарського обороту економічні суб’єкти в якості запозичених ресурсів найчастіше вдаються до кредитування. Відтак кредитні послуги банків та небанківських фінансових установ займають вагому частку на вітчизняному ринку фінансових послуг. Основними суб'єктами ринку кредитних послуг є банки, небанківські фінансові установи та інші юридичні особи, що не мають статусу фінансових установ, але мають відповідні ліцензії. Ринок кредитних послуг постійно перебуває під дією інституційних, економічних та соціально-політичних чинників, які можуть призвести до дестабілізації, спроб запровадження методів недобросовісної конкуренції, втрати довіри, i, як наслідок, призвести до порушення процесів відтворення.

У проведеному дослідженні виявлено, що банківська система $є$ безперечним лідером на ринку кредитних послуг. Проте, нині значну конкуренцію в сегменті кредитування фізичних осіб банківським установам складають різноманітні фінансові установи. Структура кредитного портфеля банків у розрізі клієнтів свідчить про те, що банківські установи достатньо активні в сегменті кредитування фізичних осіб, а тому розглядають фінансові компанії як конкурентів. На ринку зростає попит на короткострокові позики 3 терміном до одного місця. Також небанківські установи значно випереджають банківський сектор за показником приросту обсягів надання кредитних послуг. Зростає значення ринку лізингових та факторингових кредитних послуг. Ситуацію на ринку кредитних послуг ломбардів можна вважати відносно сталою, обсяг наданих кредитів цими установами зростав повільніше, ніж інші види кредитування.

Отже, дія різноманітних ринкових чинників та незавершеність процесів регуляції небанківських фінансово-кредитних установ призводить загострення конкуренції між суб'єктами ринку, до змін в організаційних формах кредитних відносин та у процесах формування попиту та пропозиції кредитних ресурсів.

Ключові слова: кредитний ринок, ринок кредитних послуг, фінансовий ринок, банки, небанківські фінансові установи, ломбарди, кредитні спілки, лізингові компанії, лізинг, факторинг.
\end{abstract}

\section{THE MAIN TENDENCIES OF DEVELOPMENT OF MODERN MARKET OF CREDIT SERVICES IN UKRAINE}

\section{Lutsk National Technical University}

Economic subjects often resort to lending as a borrowed resource in order to expand economic activity, and provide continuity of economic turnover. So, lending services of banks and non-bank institutions occupy a great part on the national market of financial services. The main subjects on credit services market are banks, non-bank institutions, and other entities that don't have a status of financial institutions but are licensed. The credit services market is constantly under the influence of institutional, economic and socio-political factors that can lead to destabilization, attempts of introduction methods of unfair competition, loss of confidence and, as a consequence, disrupt the process of reproduction.

The conducted research found that banking system is the indisputable leader on credit services market. But nowadays the various financial institutions are great competitors for the banking institutions in the segment of lending to individuals. The structure of loan portfolio of banks testifies that bank institutions are quite active in the segment of lending to individuals, so they consider financial companies as competitors. On the market the demand for short-term loans up to 1 month is increasing. Also, non-banking institutions are far ahead of the 
banking sector in terms of growth in lending services. The importance of the market of leasing and factoring credit services is increasing. The situation on the pawnshop credit services market can be considered comparatively stable, the amount of loans given by these institutions was growing more slowly than other types of lending. Thus, the effect of different market factors and incompleteness of the processes of regulation of nonbank financial institutions leads to increased competition between market subjects, changes in the organizational forms of credit relations, and in the processes of formation of demand and supply of credit resources.

Keywords: credit market, credit services market, financial market, banks, non-bank financial institutions, pawnshops, credit unions, leasing companies, leasing, factoring.

Постановка проблеми у загальному вигляді i iï зв'язок 3 важливими науковими та практичними завданнями. Незважаючи на значну кількість форм та способів залучення грошових ресурсів в господарський оборот компанії чи приватні фінанси фізичних осіб, найбільш зрозумілим, відносно простим та, насамперед, оперативним джерелом залучення коштів залишається кредитування. Як справедливо зазначає О.С. Москвічова [1, с. 19]: «...сучасне господарство є «кредитним», адже кредитні послуги посідають нині чільне місце на сучасному фінансовому ринку, господарській діяльності та економіці держави в цілому». Ринок кредитних послуг постійно перебуває в динамічному та нестійкому стані, що викликане, з одного боку, загостренням конкуренції між його суб'єктами (наприклад, через зміщення попиту на споживче кредитування до сегменту онлайн-кредитування мікрофінансовими організаціями чи іншими установами швидкого кредитування), з іншого - початком процесу передачі регулятивних функцій на ринку фінансових послуг від Нацкомфінпослуг до Національного банку та НКЦПФР. Ці та багато інших факторів, що зумовлюють динаміку ринку кредитних послуг в Україні, викликають вагомий науковий та практичний інтерес до вивчення стану, динаміки й перспектив його розвитку.

Аналіз останніх досліджень і публікацій, в яких започатковано розв'язання даної проблеми. Дослідження різноманітних аспектів функціонування кредитного ринку загалом та ринку кредитних послуг зокрема, становить значний теоретичний та практичний інтерес. Зокрема, концептуальні засади та ефективність розвитку вітчизняного кредитного ринку грунтовно досліджувалися Г.В. Миськів [2]. Частково, як елементи загального ринку фінансових послуг, ринки кредитних послуг різних фінансових інституцій розглядаються у працях Р. Бачо [3, с. 39] та С.В. Глущенко [4]. O.С. Москвічова досліджує ринок кредитних послуг через призму банківського кредитування [1]. Результати аналізу ринку кредитних послуг в Україні певною мірою представлені у публікації таких авторів як: В. Мартинюк, М. Карплюк [5], I. Рекуненко [6], Є.С. Осадчого [7]. Шануючи доробок вітчизняних та зарубіжних учених у проблематиці ринку кредитних послуг, зауважимо, що такий ринок постійно перебуває під впливом інституційних, економічних та соціально-політичних чинників. Їх вплив призводить до змін в організаційних формах кредитних відносин, змін у процесах формування попиту та пропозиції кредитних ресурсів, конкуренції між суб'єктами ринку та може спричинити порушення у процесах відтворення в економічній системі. Саме тому питання стану, проблем та перспектив розвитку ринку кредитних послуг потребують поглибленого аналізу та продовження системного опрацювання.

Цілі статті. Метою дослідження $\epsilon$ аналіз стану ринку кредитних послуг в Україні, вивчення його обсягу, виявлення основних напрямів зрушень у його структурі за видами кредитних послуг та фінансовими установами, що їх надають, а також оцінка тенденцій та перспектив його розвитку.

Виклад основного матеріалу дослідження 3 повним обгрунтуванням отриманих наукових результатів. Серед загальних передумов функціонування кредитного ринку, які мають визначальне значення у його формуванні, науковиця Г.В. Миськів виділяє «організаційно-інституційне забезпечення функціонування кредитного ринку», яке крім усього іншого «передбачає створення відповідної системи кредитних установ (банків та 
небанківських фінансових установ) для ефективної діяльності суб’єктів ринку та реалізації функцій кредитного ринку» [2, с. 92]. У нашому дослідженні ми будемо виходити 3 того, що ринок кредитних послуг $\epsilon$ вагомою частиною загального кредитного ринку та представлений установами (суб'єктами), для яких кредитна діяльність (надання різного виду кредитних послуг) є предметом (змістом) діяльності. Таким чином, основними суб'єктами (гравцями) вітчизняного ринку кредитних послуг $\epsilon$ банки та небанківські фінансові установи та інші юридичні особи, що не мають статусу фінансових установ, але мають відповідні ліцензії від регуляторів фінансового ринку, діяльність яких регламентована Законом України «Про фінансові послуги та державне регулювання ринків фінансових послуг» [8]. За цим критерієм, до фінансових установ, що можуть здійснювати діяльність у сфері кредитування, можна віднести кредитні спілки та інші небанківські кредитні установи, ломбарди, юридичні особи публічного права (ЮОПП), лізингові компанії та інші юридичні особи, що отримали відповідну ліцензію регулятора. Варто зазначити, що інформацію про стан та розвиток небанківських фінансових установ України Нацкомфінпослуг оприлюднюе із періодичною зміною методичного підходу щодо їх групування за видами, що ускладнює системний аналіз їх діяльності. Крім того, зареєстровані у Нацкомфінпослуг фінансові компанії мають ліцензії на різні види діяльності на ринку фінансових послуг, тому їх представництво на ринку кредитних послуг у таблиці 1 буде подано за видами здійснюваних кредитних операцій.

Розглянемо, який обсяг кредитних послуг в Україні задовольнявся упродовж 2017-2018 років банківськими установами та небанківським сектором (табл.1).

Ємність ринку кредитних послуг, сформованого банками

Таблиця 1

та небанківськими фінансовими установами, млн. грн.

\begin{tabular}{|c|c|c|c|c|}
\hline \multirow{2}{*}{ Показники } & \multirow{2}{*}{$2017 p}$. & \multirow{2}{*}{ 2018p. } & \multicolumn{2}{|c|}{$\begin{array}{l}\text { Темп приросту } \\
2018 \text { p./2017p. }\end{array}$} \\
\hline & & & $\begin{array}{c}\text { абсолютний, } \\
\text { млн. грн. }\end{array}$ & відносний, \% \\
\hline $\begin{array}{l}\text { Банківські установи } \\
\text { (кредити надані клієнтам) }\end{array}$ & 1036745,0 & 1118860,0 & 82115,0 & 7,92 \\
\hline $\begin{array}{l}\text { Фінансові компанії } \\
\text { (надання коштів у позику, в т.ч. і на умовах } \\
\text { фінансового кредиту) }\end{array}$ & 27382,6 & 47856,9 & 20474,3 & 74,77 \\
\hline $\begin{array}{l}\text { Фінансові компанії } \\
\text { (надання послуг } 3 \text { факторингу) }\end{array}$ & 31363,2 & 48105,0 & 16741,8 & 53,38 \\
\hline $\begin{array}{l}\text { Фінансовий лізинг (послуги, надані } \\
\text { фінансовими компаніями та юридичними } \\
\text { особами - лізингодавцями без статусу } \\
\text { фінансової компанії) }\end{array}$ & 12967,6 & 22193,1 & 9225,5 & 71,14 \\
\hline
\end{tabular}

Примітка. Сформовано та розраховано на основі даних джерел [9; 10]

Поза сумнівом, лідерами за обсягом операцій на ринку кредитних послуг $є$ банківські установи. Проте за приростом обсягів надання кредитних послуг небанківські установи значно випереджають банківський сектор. Зростання ролі небанківських фінансових установ на ринку кредитування опосередковано підтверджується результатами опитувань про умови банківського кредитування, які щоквартально проводяться НБУ. Так, окремі респонденти у I кварталі 2020 року відзначали «конкурентний тиск зі сторони інших фінустанов, що негативно впливало на кредитний попит» [11, с. 1].

Що стосується структури кредитного портфеля банків, то слід відзначити деяке зростання частки кредитів, наданих фізичним особам (на 2,41\% у 2019 році проти 2018 року) і зменшення частки кредитів, наданих суб'єктам господарювання (на 2,61\% за відповідний період) (рис.1). 


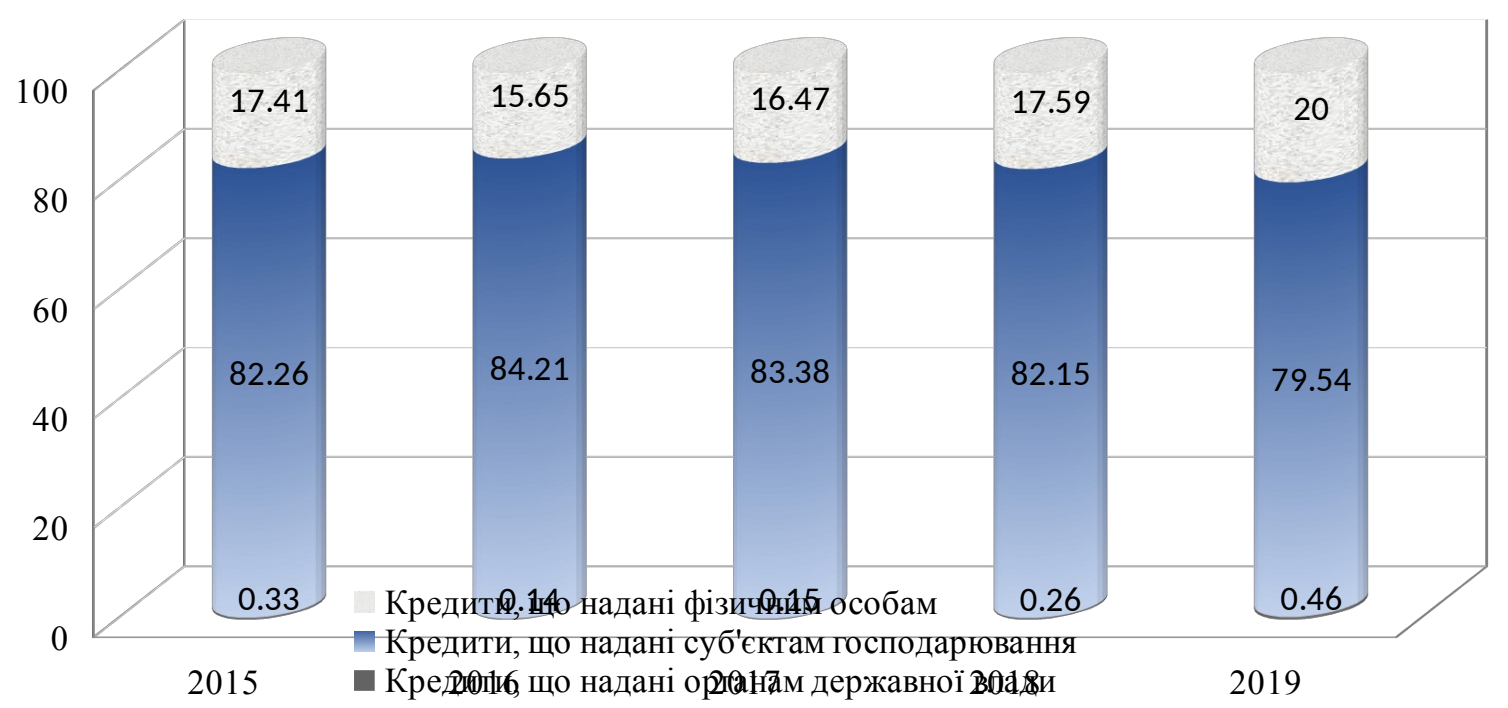

Рис. 1. Клієнтська структура обсягу кредитів, наданих банками ${ }^{1}, \%$.

Примітки:

1. У структурі не представлено частку кредитів, надану банками небанківським кредитним установам, оскільки обсяг такого кредитування менше, ніж $0,01 \%$.

2. Побудовано на основі джерела [10]

Представлена на рисунку 1 структура кредитного портфеля банків у розрізі клієнтів також свідчить про те, що банківські установи достатньо активні в сегменті кредитування фізичних осіб, а тому дійсно вбачають у фінансових компаніях прямих конкурентів.

3 метою оцінки динаміки обсягів кредитів, наданих банками, представимо графічно обсяги кредитів, наданих суб'єктам господарювання кредитів та кредитів, наданих фізичним особам (рис. 2).

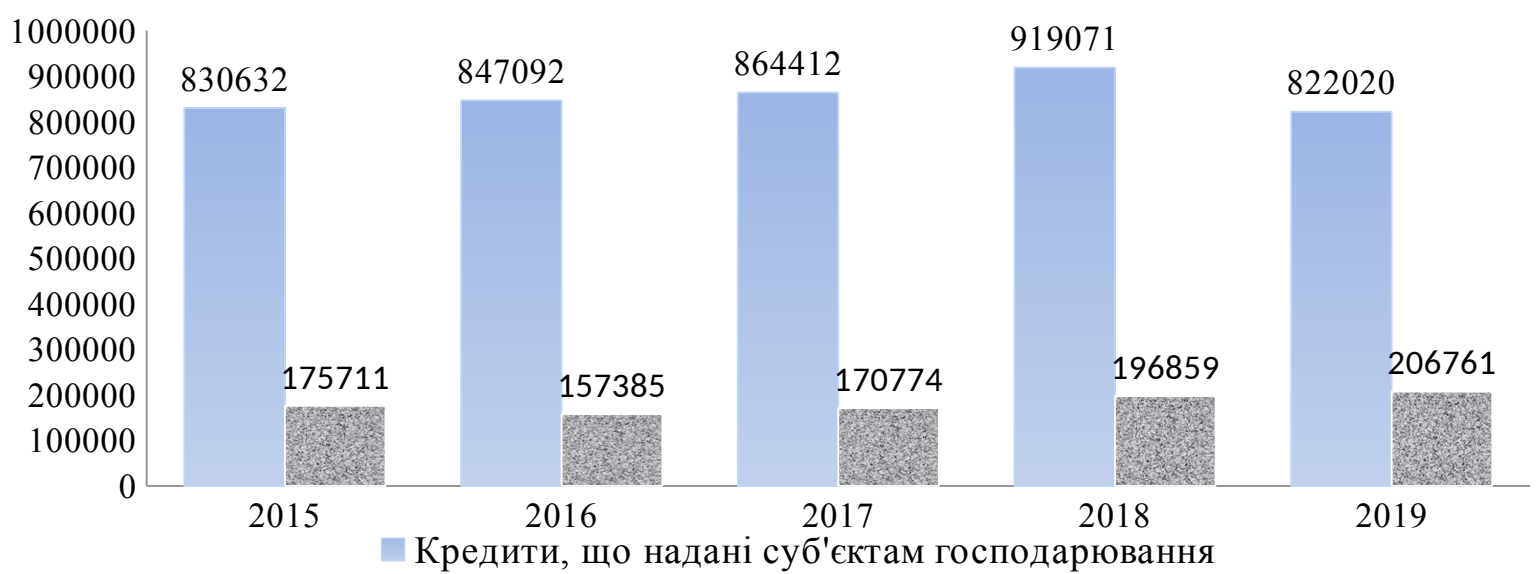

Рис. 2. Динаміка обсягу кредитів, наданих банками основним групам позичальників, \%.

Примітка. Побудовано на основі даних джерела [10]

3 графіка видно, що обсяг кредитів суб’єктам господарювання станом на кінець 2019 року є найменшим упродовж усього аналізованого періоду. Обсяг кредитування фізичних осіб, навпаки, має чітку тенденцію до зростання. Загалом обсяг кредитів суб'єктам господарювання зменшився у 2019 році, порівняно із 2018 роком на 97051 млн. грн., (10,56\%), а обсяг кредитів фізичним особам за цей період зріс на 9902 млн. 
грн. (5,03\%). Загалом виявлена тенденція $\epsilon$ негативною, адже скорочення обсягів кредитування суб'єктів господарювання відбулось у 2019 році на тлі скорочення облікової ставки з 18\% у лютому до 13,5\% у грудні.

3 огляду на значний приріст кредитування у секторі небанківських фінансових установ, розглянемо, як змінювалась кількість суб'єктів, що пропонують послуги на небанківському кредитному сегменті вітчизняного ринку фінансових послуг (табл. 2).

Таблиця 2

Динаміка кількості небанківських фінансових установ на ринку кредитних послуг

\begin{tabular}{|l|c|c|c|c|c|c|}
\hline \multicolumn{1}{|c|}{ Показники } & $2014 \mathrm{p}$. & $2015 \mathrm{p}$. & $2016 \mathrm{p}$. & $2017 \mathrm{p}$. & 2018p. & $\begin{array}{c}\text { 3a 9 } \\
\text { місяців } \\
2019 \mathrm{p} .\end{array}$ \\
\hline Кредитні спілки & 589 & 588 & 462 & 378 & 358 & 348 \\
\hline Ломбарди & 477 & 482 & 456 & 415 & 359 & 333 \\
\hline $\begin{array}{l}\text { Фінансові компанії (кількість зареєстрованих } \\
\text { інших кредитних установ) }\end{array}$ & 92 & 110 & 130 & 113 & 130 & $\ldots$ \\
\hline $\begin{array}{l}\text { Фінансові компанії, що мають діючу } \\
\text { ліцензію з права надавати послуги } \\
\text { факторингу }\end{array}$ & 264 & 457 & 545 & 492 & 589 & 633 \\
\hline $\begin{array}{l}\text { Юридичні особи без статусу фінансової } \\
\text { компанії, що мають діючу ліцензію з права } \\
\text { надавати послуги фінансового лізингу }\end{array}$ & 267 & 268 & 202 & 183 & 167 & 165 \\
\hline
\end{tabular}

Примітка. Сформовано на основі даних джерел $[9 ; 12 ; 13]$

Загалом, має місце тенденція до зменшення загальної кількості небанківських фінансових установ, що займаються наданням кредитних послуг. Так, у 2018 році, порівняно із 2014 роком кількість кредитних спілок скоротилася на 39\%, ломбардів - на $24,7 \%$, компаній 3 ліцензією на послуги фінансового лізингу - на 38,2\%. Проте фінансові компанії нарощували кількість ліцензій на здійснення послуг факторингу: у 2018 році їх кількість зросла в 2,2 рази, порівняно із 2014 роком. А за 9 місяців 2019 року їх кількість збільшилась ще на 44 компанії, порівняно із даними 2018 року. Таким чином, можна висловити припущення про зростання попиту на послуги факторингу на вітчизняному ринку кредитних послуг.

Розглянемо, яким чином відбувається розподіл ринкових часток між небанківськими фінансовими установами на ринку кредитних послуг. 3 цією метою представимо динаміку обсягів кредитних послуг за їх основними видами в розрізі установ, що їх пропонують (табл. 2).

Таблиця 2

Динаміка обсягів кредитних послуг в небанківському сегменті фінансового ринку, млн. грн.

\begin{tabular}{|l|c|c|c|c|c|}
\hline \multicolumn{1}{|c|}{ Показники } & $2014 \mathrm{p}$. & $2015 \mathrm{p}$. & $2016 \mathrm{p}$. & $2017 \mathrm{p}$. & $2018 \mathrm{p}$. \\
\hline 1. Кредити, видані членам кредитних спілок & 1994,4 & 1792,7 & 1799,5 & 1902,3 & 2018,0 \\
\hline $\begin{array}{l}\text { 2. Обсяг виданих кредитів кредитними } \\
\text { установами 1 }\end{array}$ & 5138,5 & 7691,0 & 13388,0 & 27382,6 & 47856,9 \\
\hline $\begin{array}{l}\text { 3. Вартість договорів фінансового лізингу, } \\
\text { укладених фінансовими компаніями }\end{array}$ & 257,4 & 20,2 & 67,3 & 153,4 & 673,8 \\
\hline $\begin{array}{l}\text { 3. Вартість договорів факторингу, укладених } \\
\text { фінансовими компаніями }\end{array}$ & 23525,7 & 16555,9 & 16887,5 & 31363,2 & 48105,0 \\
\hline $\begin{array}{l}\text { 4. Сума наданих фінансових кредитів } \\
\text { ломбардами }\end{array}$ & 8410,8 & 12459,7 & 16718,0 & 16389,0 & 16442,3 \\
\hline $\begin{array}{l}\text { 5. Вартість договорів фінансового лізингу, } \\
\text { укладених юридичними особами - } \\
\text { лізингодавцями }\end{array}$ & 7181,0 & 6241,4 & 9755,0 & 12814,2 & 21519,3 \\
\hline 6. Обсяг виданих кредитів ЮОПП & 2724,2 & 2437,5 & 6520,1 & $\ldots$ & $\ldots$ \\
\hline
\end{tabular}

Примітка:

1. Починаючи із 2017 року - надання коштів у позику фінансовими компаніями разом з ІКУ та фінансовими установами - ЮОПП

2. Сформовано на основі даних джерел $[9 ; 13]$ 
Розглядаючи ринок послуг кредитних спілок, варто відмітити його стійке зростання упродовж всього аналізованого періоду. Станом на 31.12.2018p. обсяг кредитів, наданих членам кредитних спілок, становлять 2018,0 млн. грн. та порівняно 3 31.12.2017p. збільшилися на 6,1\% (115,7 млн. грн.). Середній розмір кредиту на одного члена кредитної спілки, за даними Нацкомфінпослуг, становить 17,1 тис. грн. Разом 3 тим, слід зазначити зменшення кількості кількість членів кредитних спілок: на кінець 2018 року, за даними регулятора, вона становила 479,0 тис. осіб, що на 85,1 тис. осіб $(15,1 \%)$ менше, ніж на кінець 2017 року [9].

Як було зазначено вище, до 2017 року кредитні установи в Україні були представлені кредитними спілками, іншими кредитними установами та юридичними особами публічного права. Загалом, станом на 31.12.2018 року в Державному реєстрі фінансових установ міститься інформація про 940 фінансових компаній, відомості про кредитні послуги яких подається разом із показниками ІКУ та фінансових установ ЮОПП [9]. Сдиним справедливим висновком щодо збільшення обсягів кредитування усіма фінансовими компаніями вбачається факт значного зростання ринку мікрокредитування (у т.ч. онлайн-позик), що демонструє приріст за показником надання коштів у позику, в т.ч. і на умовах фінансового кредиту, на 82,5\%. Як зазначає Укрінформ, із посиланням на Нацкомфінпослуг [14]: «Основними споживачами фінансових послуг є фізичні особи, малий та середній бізнес. Більше половини - 55,4\% від загальної суми укладених договорів 3 надання позик припадає на кредити, що надані фізичним особам. При цьому 84,3\% від кількості укладених договорів припадала на договори, термін дії яких не перевищував 30 днів. В середньому, фізичні особи брали в борг 3276 грн.». 3 одного боку це пояснюється поліпшенням споживчих настроїв населення, з іншого - може бути свідченням низької фінансової обізнаності споживачів, що не завжди розуміють реальну вартість таких позик, небажанням демонструвати свої кредитні історії, що $\epsilon$ обов'язковою умовою банківського кредитування і т.п.

Певні зрушення демонструє ринок фінансового лізингу, який в Україні представлений фінансовими компаніями, що мають діючі ліцензії на цей вид послуг та юридичними особами (лізингодавцями), що своїм статусом не $є$ фінансовими компаніями, проте мають ліцензію на право надання послуг з фінансового лізингу. Протягом 2018 року близько 97,0\% усіх послуг фінансового лізингу надано юридичними особами - суб'єктами господарювання, які не є фінансовими установами, а 95,6 \% лізингових послуг припадає лише на 20 найбільших юридичних осіб лізингодавців. Як зазначає Нацкомфінпослуг: «За підсумками 2018 року спостерігається збільшення кількості договорів фінансового лізингу на 33,2\% (2571 одиниці) порівняно з 2017 роком. При цьому, вартість договорів фінансового лізингу збільшилась на 71,1\% (на 9225,5 млн. грн.) [9].

Ситуацію на ринку кредитних послуг ломбардів можна вважати відносно сталою, обсяг наданих кредитів цими установами у 2018 році зріс лише на 9\%, порівняно із попереднім, 2017 роком.

Впевнене зростання демонструє ринок факторингу, приріст послуг якого у 2018 році склав 53,3\%, що в абсолютному вираженні становить 16741,8 млн. грн. Цікаво, що кількість договорів факторингу, укладених упродовж 2018 року, $є$ на 0,1\% меншою, порівняно з цим показником за 2017 рік.

Висновки. Таким чином, панівне становище на ринку кредитних послуг в Україні традиційно належить банківським установам. Проте, в останні роки, приріст обсягів кредитних послуг, що надаються небанківськими фінансовими установами значно перевищує зростання кредитних портфелів банків. Отже, варто очікувати загострення конкуренції на ринку кредитних послуг, особливо в сегменті кредитування фізичних осіб. Швидкість і простота одержання кредитів, пропонованих деякими сервісами онлайн-кредитування, зробили ці послуги надзвичайно популярними серед населення, незважаючи на значні відсотки. 
Загальною негативною тенденцією на ринку кредитних послуг в Україні вбачається зменшення обсягів банківського кредитування суб'єктів господарювання, що може бути свідченням уповільнення економічного зростання. Разом 3 тим, варто відмітити зростання ринків лізингових та факторингових кредитних послуг.

Таким чином, на сучасному ринку кредитних послуг спостерігається загострення конкуренції між суб'єктами ринку, зміни у попиті на кредитні ресурси, а також в організаційних формах кредитних відносин, що зумовлено дією як ринкових чинників, так і незавершеністю процесу в системі державної регуляції сфери небанківських фінансово-кредитних установ.

\section{Список бібліографічного опису:}

1. Москвічова О. С. Державне регулювання кредитних послуг в умовах банківської кризи : дис. ...канд. екон. наук : 08.00.03. Львів, 2014. 288 c.

2. Миськів, Г. В. Функціонування та розвиток кредитного ринку України : дис. ... докт. екон. наук : 08.00.08. Київ, 2016. 533 с.

3. Бачо Р.Й. Ринки небанківських фінансових послуг: регулювання розвитку (інституційні та аналітичні аспекти): монографія. Ужгород: Вид-во ТОВ«РІК-У», 2016. 448 с.

4. Глущенко С.В. Кредитний ринок: інститути та інструменти : навч.посіб. К.: НаУКМА, 2009. 153 с.

5. Мартинюк В., Карплюк М. Вітчизняний ринок кредитних послуг та його роль у розвитку підприємництва. Сталий розвиток стан та перспективи : матеріали міжнар. наук. симпозіуму SDEV‘2018, (Львів-Славське, 28 лют. - 3 бер. 2018 р.). Львів, 2018. С. 241-244. URL: http://ena.lp.edu.ua:8080/handle/ntb/43301

6. Рекуненко I.I., Струк Л. Є. Вплив конкуренції на стан кредитного ринку України. Сучасні підходи до управління підприємством : збірник наук. праць IV Bсеукр. наук.-практ. конф. : у двох томах. Київ, $2013 . \quad$ T. $2 . \quad$ C. $312-317 . \quad$ URL: http://essuir.sumdu.edu.ua/handle/123456789/58695.

7. Осадчий Є. С. Особливості діяльності фінансово-кредитних установ в Україні. Економіка і суспільство. 2016. №5. С. $375-382$.

8. Про фінансові послуги та державне регулювання ринків фінансових послуг: Закон України від 12.07.2001 № 2664-III / ВР України. URL: https://zakon.rada.gov.ua/laws/show/2664-14 (дата звернення: 28.02.2020).

9. Інформація про стан і розвиток кредитних установ України. Офіційний сайт Національної комісії, що здійснює державне регулювання у сфері ринків фінансових послуг. URL: https://www.nfp.gov.ua/ua/Informatsiia-pro-stan-i-rozvytok-kredytnykh-ustanovUkrainy.html.

10. Основні показники діяльності банків України. Офіційний сайт Національного банку України. URL: https://bank.gov.ua/statistic/supervision-statist/data-supervision\#1.

11. Опитування про умови банківського кредитування, I квартал 2020 року. Офіційний сайт Національного банку України. URL: https://bank.gov.ua/news/all/opituvannya-pro-umovi-bankivskogo-kredituvannya-i-kvartal-2020-roku

12. Аналіз ринку онлайн-мікрокредитування України. 2019 рік. URL: https://pro-consulting.ua/ua/issledovanie-rynka/analiz-rynkaonlajn-mikrokreditovaniya-ukrainy-2019-god.

13. Ринок небанківських фінансових послуг. Офіційний сайт Національного рейтингового Агентства «Рюрик». URL: http://rurik.com.ua/our-research/branch-reviews/1191.

14. В Україні спостерігається стале зростання ключових показників розвитку мікрофінансових організацій (МФО). Укрінформ. URL: https://www.ukrinform.ua/rubric-economy/2800122-mikrokredituvanna-v-ukraini-prodovzue-zrostati-ekspert.html

\section{References:}

1. Moskvichova O. S. Derzhavne rehuliuvannia kredytnykh posluh v umovakh bankivskoi kryzy : dys. ...kand. ekon. nauk : 08.00.03. Lviv, 2014. $288 \mathrm{~s}$.

2. Myskiv, H. V. Funktsionuvannia ta rozvytok kredytnoho rynku Ukrainy : dys. ... dokt. ekon. nauk : 08.00.08. Kyiv, 2016. 533 s.

3. Bacho R.I. Rynky nebankivskykh finansovykh posluh: rehuliuvannia rozvytku (instytutsiini ta analitychni aspekty): monohrafiia. Uzhhorod: Vyd-vo TOV«RIK-U», 2016. $448 \mathrm{~s}$

4. Hlushchenko S.V. Kredytnyi rynok: instytuty ta instrumenty : navch.posib. K.: NaUKMA, 2009. $153 \mathrm{~s}$

5. Martyniuk V., Karpliuk M. Vitchyznianyi rynok kredytnykh posluh ta yoho rol u rozvytku pidpryiemnytstva. Stalyi rozvytok - stan ta perspektyvy : materialy mizhnar. nauk. sympoziumu SDEV‘2018, (Lviv-Slavske, 28 liut. - 3 ber. 2018 r.). Lviv, 2018. S. $241-244$.

6. Rekunenko I.I., Struk L. Ye. Vplyv konkurentsii na stan kredytnoho rynku Ukrainy. Suchasni pidkhody do upravlinnia pidpryiemstvom : zbirnyk nauk. prats IV Vseukr. nauk.-prakt. konf. : u dvokh tomakh. Kyiv, 2013. T. 2. S. 312-317. URL: http://essuir.sumdu.edu.ua/handle/123456789/58695.

7. Osadchyi Ye. S. Osoblyvosti diialnosti finansovo-kredytnykh ustanov v Ukraini. Ekonomika i suspilstvo. 2016. №5. S. 375-382.

8. Pro finansovi posluhy ta derzhavne rehuliuvannia rynkiv finansovykh posluh: Zakon Ukrainy vid 12.07.2001 № 2664-III / VR Ukrainy. URL: https://zakon.rada.gov.ua/laws/show/2664-14 (Accessed: 28.02.2020).

9. Informatsiia pro stan i rozvytok kredytnykh ustanov Ukrainy. Ofitsiinyi sait Natsionalnoi komisii, shcho zdiisniuie derzhavne rehuliuvannia u sferi rynkiv finansovykh posluh. URL: https://www.nfp.gov.ua/ua/Informatsiia-pro-stan-i-rozvytok-kredytnykh-ustanovUkrainy.html.

10. Osnovni pokaznyky diialnosti bankiv Ukrainy. Ofitsiinyi sait Natsionalnoho banku Ukrainy. URL: https://bank.gov.ua/statistic/supervision-statist/data-supervision\#1.

11. Opytuvannia pro umovy bankivskoho kredytuvannia, I kvartal 2020 roku. Ofitsiinyi sait Natsionalnoho banku Ukrainy. URL: https://bank.gov.ua/news/all/opituvannya-pro-umovi-bankivskogo-kredituvannya-i-kvartal-2020-roku

12. Analiz rynku onlain-mikrokredytuvannia Ukrainy. 2019 rik. URL: https://pro-consulting.ua/ua/issledovanie-rynka/analiz-rynka-onlajnmikrokreditovaniya-ukrainy-2019-god.

13. Rynok nebankivskykh finansovykh posluh. Ofitsiinyi sait Natsionalnoho reitynhovoho Ahentstva «Riuryk». URL: http://rurik.com.ua/our-research/branch-reviews/1191.

14. V Ukraini sposterihaietsia stale zrostannia kliuchovykh pokaznykiv rozvytku mikrofinansovykh orhanizatsii (MFO). Ukrinform. URL: https://www.ukrinform.ua/rubric-economy/2800122-mikrokredituvanna-v-ukraini-prodovzue-zrostati-ekspert.html.

Дата подання публікації 14.03.2020p. 